Canadian University Music Review

Canadian University Music Review

Revue de musique des universités canadiennes

\title{
The Project Ahead: Some Thoughts on Developing a Popular Music Curriculum
}

\section{Paul Théberge}

Volume 21, numéro 1, 2000

Music Studies in the New Millennium : Perspectives from Canada Les études en musique dans le nouveau millénaire : perspectives canadiennes

URI : https://id.erudit.org/iderudit/1014476ar

DOI : https://doi.org/10.7202/1014476ar

Aller au sommaire du numéro

\section{Éditeur(s)}

Canadian University Music Society / Société de musique des universités canadiennes

\section{ISSN}

0710-0353 (imprimé)

2291-2436 (numérique)

Découvrir la revue

Citer cet article

Théberge, P. (2000). The Project Ahead: Some Thoughts on Developing a Popular Music Curriculum. Canadian University Music Review / Revue de musique des universités canadiennes, 21(1), 28-39.

https://doi.org/10.7202/1014476ar

\section{Résumé de l'article}

Arguing that past attempts at introducing popular music into the curriculum have taken place primarily at the level of the individual course, the author argues that a more extensive and integrated approach to developing academic programs in popular music is now needed. The model for such a program must be both multidisciplinary and interdisciplinary in character and must include the full participation of departments and faculties of music. Consideration is given to the special demands placed on music programs in terms of the need to rethink the structures and pedagogical practices associated with present-day higher education in music.
All Rights Reserved @ Canadian University Music Society / Société de musique des universités canadiennes, 2000
Ce document est protégé par la loi sur le droit d'auteur. L'utilisation des services d'Érudit (y compris la reproduction) est assujettie à sa politique d'utilisation que vous pouvez consulter en ligne.

https://apropos.erudit.org/fr/usagers/politique-dutilisation/ 


\section{THE PROJECT AHEAD: SOME THOUGHTS ON DEVELOPING A POPULAR MUSIC CURRICULUM}

\section{Paul Théberge}

Popular music studies has come of age. Twenty-five years ago it would have been difficult to find a single, regularly offered university-level course in popular music anywhere in Canada. Today, even a casual survey of university calendars and Web sites reveals a wide variety of such courses offered in a diverse range of institutional settings: from courses in music and popular culture offered in departments of English, communications or cultural studies, to surveys of rock history and musical style in departments and faculties of music, to courses in sound recording and the music business found in professional colleges and the polytechnic schools. Furthermore, the number of book titles (and book series) devoted to popular music has been growing steadily in quantity and diversity for at least a decade and, perhaps more significantly, the recent appearance of "textbook" histories, anthologies, and surveys of popular music theory attest to the burgeoning market for university-level readers in popular music. ${ }^{1}$ From the standpoint of the development of an academic community within the field, a number of academic journals, devoted in whole or in part to the field of popular music, have been launched during the past two decades, and the International Association for the Study of Popular Music (IASPM), now in its twentieth year of operation, has fostered the development of a network of affiliated organizations-from Scandinavia to Australia, from Europe to the Americas and to the Far East-sponsoring conferences and symposia at both the national and international level. And finally, in many recent university job announcements, most notably in advertisements for positions in music departments, popular music is finally beginning to be treated as a legitimate field of specialization and not simply as an "asset" of potential

1 This trend began at least a decade ago with the publication of Simon Frith and Andrew Goodwin, eds., On Record: Rock, Pop, and the Written Word (New York: Pantheon, 1990); and Richard Middleton, Studying Popular Music (Milton Keynes: Open University Press, 1990); it has gained considerable momentum in recent years with the publication of titles such as Reebee Garafalo, Rockin' Out: Popular Music in the USA (Needham Heights, Mass.: Allyn and Bacon, 1997); Keith Negus, Popular Music in Theory (Hanover, N.H.: Wesleyan University Press, 1996); Bruce Horner and Thomas Swiss, eds., Key Terms in Popular Music and Culture (Oxford: Blackwell, 1999); and Simon Frith and Will Straw, eds., The Cambridge Companion to Pop and Rock (Cambridge: Cambridge University Press, 2001). In addition, major encyclopedia projects in popular and world musics are also under way, sponsored by publishers such as Continuum and Garland. 
candidates-the term "asset" too often betraying the marginal status of popular music in most academic programs in the past.

Yet, despite these gains, the presence of popular music in most university curricula in Canada (and indeed throughout North America) remains at the level of the individual course: few departments offer more than one or two courses in the area and, even among those that do, little resembling a broadly based, comprehensive program of study could be said to exist. ${ }^{2}$ But perhaps more serious than the paucity of existing programs is the fact that when one compares the syllabi for courses offered in different faculties and departments, it is sometimes difficult to discern anything resembling a commonality in approach or literature. Of course, this might (and perhaps should) be construed as a healthy thing, an expression of the essential, interdisciplinary nature of the field. ${ }^{3}$ It is equally, however, the result of a diverse set of discipline-based assumptions that continue to define popular music, as an object of study, in significantly different ways. What I want to argue here is not so much that we need a common paradigm for the study of popular music, at least not at the level of the individual course, but rather that, as the field continues to grow and take on a more significant role in university curricula, the requirement of more fully developed models of what a program in popular music studies can or should be will become critical.

One of the immediate problems to be faced in developing a popular music curriculum is the fact that there exists no obvious disciplinary home within which such a project could be housed. While much of the foundational work of the past two decades or so in popular music studies has been conducted by individuals working within sociology, cultural studies, and related fields, popular music has remained surprisingly marginal to these areas of scholarship as a whole. For example, within Canada, there have been significant historical

\footnotetext{
2 Programs in popular music studies certainly exist elsewhere, most notably in the UK: for example, at the well-known Institute of Popular Music in Liverpool and at Salford University. But outside the UK such programs remain few and far between. The Department of Musicology at UCLA, with its high concentration of courses in popular music (at both undergraduate and graduate levels) is something of an exception in North America; however, its functional separation from the Department of Music (performance and composition) would seem to suggest that its efforts in the area may remain separate from music pedagogy as a whole. In Canada, Carleton University's music program has long been a leader in the integration of popular music within a traditional music curriculum and, with its current location within the School for Studies in Art and Culture, it offers considerable opportunity for interdisciplinary study; the small size of the program, however, and its lack of a graduate program has limited, to some extent, the potential scope of its innovations. Even with the recent launching of an undergraduate degree program in popular music studies in the Department of Music History at the University of Western Ontario, the state of affairs in Canada has changed little: while the program holds much promise for the future, the specifics of its curriculum and its mode of delivery are still in the process of being defined.

3 Perhaps one of the most salient examples of the positive side of pop music as an interdisciplinary field of study can be found in the publication of a special double issue of the Journal of Popular Music Studies, 9-10 (1997-1998). The issue consists of a number of reflections on teaching popular music in (and out of) the academy, followed by some thirty syllabi drawn from courses in popular music offered in a wide range of departments and programs, many of them including extensive bibliographies. The sheer range of subject matter and pedagogical approach represented in the various syllabi is indeed impressive, and a testimony to the present richness and diversity of the field.
} 
links between the emergence of the field of cultural studies and that of communications. Furthermore, given the degree to which popular music can be seen to traverse all forms of media-from print to live performance, from sound recording to radio, film, television, and the Internet-it would appear to be an ideal form through which to examine the effects and interrelationships between cultural products and various aspects of media and communications. Ironically, popular music, as a form of cultural expression, and even sound recording as a medium, have been routinely neglected within much of the communications literature for many years. And while this lacuna has begun to be addressed in some introductory textbooks in the field (and in the work of individual scholars as wellit), it is not unusual to find an otherwise thorough and comprehensive anthology, such as Crowley and Heyer's Communication in History: Technology, Culture, Society, 5 that skips immediately from discussions of technologies such as the telegraph and telephone to those of radio and sound film, thereby ignoring entirely the emergence of sound recording, both as a medium of mass communication and as a key factor in the redefinition of musical culture in the twentieth century. Popular music does receive passing attention in the latest edition of this volume, but only in relation to music videos. Not surprisingly, less emphasis is placed on popular music in this instance than on the importance of television.

During the past decade, a number of significant contributions to the field of popular music studies have also come from the ranks of musicologists ${ }^{6}$ and, while there are those who believe that popular "music" has its rightful place within the music academy, there are significant barriers within most music faculties and departments, as they are currently structured, that make such a proposition problematic at best. A discussion of some of these barriers will be taken up below but, for the moment, it is perhaps important to note that the inroads made by individual musicologists in the area of popular music have not, by and large, been followed by the majority of their colleagues in other areas of music (i.e., in performance, analysis and composition). Ultimately, as I will argue, the participation of music departments and faculties may well be essential for the future of popular music as a program of study but, for popular music to thrive in the context of most university music departments, it will first have to be embraced (and not simply tolerated) by a wider range of individuals, and accepted as a legitimate part of the music curriculum as a whole.

In stating this, however, I do not wish to imply that the only significant divisions for popular music within the university are those that supposedly

4The work of Anahid Kassabian is notable in this respect, in that she has pushed further than almost anyone else within the field of communication studies towards a definition that includes background music and other mediated cultural forms as part of our basic understanding of popular music. See, for example, her essay entitled, "Popular," in Horner and Swiss, Key Terms, 113-23.

5David Crowley and Paul Heyer, eds., Communication in History: Technology, Culture, Society, 3rd ed. (New York: Longman, 1999).

6 Among the more significant have been Robert Walser, Running with the Devil: Power, Gender, and Madness in Heavy Metal Music (Hanover, N.H.: Wesleyan University Press, 1993); and David Brackett, Interpreting Popular Music (Cambridge: Cambridge University Press, 1995). 
exist between socio/cultural approaches and musicological ones, as is so often assumed. Indeed, there are numerous differences within social, economic, technical, and cultural approaches to the study of music that suggest that they should not be considered as a unified perspective, in the same way as there are inherent divisions within music faculties that have a bearing on how a popular music curriculum might be conceived and implemented. The problems-and possibilities - are thus multilateral in nature, existing both within and between departments and faculties, between universities and technical colleges.

It seems to me that if a truly comprehensive program of study in popular music is to be created, it will necessarily be a multidisciplinary project, one that brings together the combined strengths of multiple perspectives drawn from a number of sources within the university. Of course, the concept of inter-, multi- or cross-disciplinary programs is not new within the academy, and such programs have been both championed and much maligned in the past. Too often, especially in the context of a decade or more of cutbacks in funding, administrators have seen them as a convenient means of enhancing program offerings while rationalizing infrastructure expenditures and maximizing teaching resources. Such contradictory aims, however, can stifle rather than foster the development of innovative programs and, as will be argued, the implementation of a full program in popular music studies will, in most cases, require some level of investment in new facilities, technologies and faculty appointments.

At the outset, however, the initiative for the development of a multi- or interdisciplinary approach to popular music studies should not come from administrators, but from faculty already involved in the research and teaching of popular music. Evidence that popular music scholars are reaching across disciplinary boundaries, perhaps even more so than in the past, suggests that such a development is inevitable. For example, the publication of Simon Frith's Performing Rites ${ }^{7}$ suggests that scholars working from within sociological and cultural studies perspectives are willing to deal with issues of aesthetics and cultural values-issues that were once carefully avoided or thoroughly circumscribed by specific sociological theories and concerns. Similarly, in the 1980s, when music video and MTV were still new, film studies scholars were quick to enter the fray, offering sophisticated theoretical assessments of the significance of these forms. Much of this work proved to be of transient interest-few film scholars maintained a scholarly investment in the area-but more importantly, the narrative and psychoanalytic models of analysis that were often brought to bear on music video were not well suited to the medium, and often ignored the specific manner in which fans relate to popular music. Meanwhile, the study of film music had largely become limited to studies of conventional musical scores, often ignoring the growing importance of popular music in contemporary film making. ${ }^{8}$ More recently, with the publication of works such

\footnotetext{
7Simon Frith, Performing Rites: On the Value of Popular Music (Cambridge, Mass.: Harvard University Press, 1996).

8 Although Anahid Kassabian's Hearing Film: Tracking Identifications in Contemporary Hollywood Film Music (New York: Routledge, 2001) represents a welcome change of direction in this respect.
} 
as Jeff Smith's The Sounds of Commerce: Marketing Popular Film Music, ${ }^{9}$ there seems to be a renewed interest in the popular music score, one that attempts to take into account both the economic conditions of its production as well as its aesthetic impact on the structure and reception of narrative film; and in the area of music video, the attempts of scholars such as Carol Vernallis to formulate an aesthetics appropriate to the medium are also noteworthy. 10 What is refreshing about these studies is that, firstly, they begin with the presence of popular music in film-or, in the case of Vernallis, with music video-as givens rather than as a pretext for a lament for older forms of narrative/image/music relations. And secondly, these studies have tended to stray from some of the older theoretical predilections and orthodoxies towards a more general set of cultural theories and aesthetic propositions that make them more immediately relevant to a wider audience.

As important as these developments are, none is as potentially significant, I believe, as the turn in musicology towards modes of music analysis that are informed by broad currents in contemporary cultural, social, and linguistic theory. Beginning with Kerman's well-known call for a wholesale rethinking of the musicological paradigm, ${ }^{11}$ and continuing in the work of Lawrence Kramer and a host of more recent studies, ${ }^{12}$ musicology has made substantial gains in developing alternatives to the conventional theoretical and methodological models that have dominated the field for so long. That this has largely taken place without a concomitant displacement of the dominant canon is as disturbing, however, as it is encouraging: much of the recent theorizing simply offering one more reading, albeit a sometimes oppositional one, of the standard repertoire. Still, the engagement with theoretical paradigms from outside the world of conventional musicology offers a potential common ground upon which interdisciplinary research and teaching in popular music can perhaps find a foothold within an otherwise conventional music curriculum.

It is necessary to have this common ground because firstly, a broad curriculum in popular music studies needs to be both multidisciplinary-drawing on contributions from a number of distinct fields of inquiry, each with their own characteristic objects of study, areas of interest, and emphasis-but also interdisciplinary in the sense that courses in popular music offered within any given institutional setting should ideally reach beyond the immediate boundaries that define the specific disciplinary home towards a common, or at least

9 Jeff Smith, The Sounds of Commerce: Marketing Popular Film Music (New York: Columbia University Press, 1998). In a similar vein, see John Mundy, Popular Music on Screen: From Hollywood Musical to Music Video (Manchester: Manchester University Press, 1999).

10See, for example, "The Aesthetics of Music Video: The Relation of Music and Image in Madonna's Cherish," Popular Music 17, no. 2 (1998): 153-85.

11 Joseph Kerman, Contemplating Music: Challenges to Musicology (Cambridge, Mass.: Harvard University Press, 1985).

12For example, see Lawrence Kramer, Music as Cultural Practice, 1800-1900 (Berkeley: University of California Press, 1990); for a useful overview of issues and concerns, see John Shepherd and Peter Wicke, Music and Cultural Theory (Cambridge: Polity Press, 1997). Among some of the recent studies, certainly those dealing with gender and sexuality have been among the most provocative: for example, Philip Brett et al., eds., Queering the Pitch: The New Gay and Lesbian Musicology (New York: Routledge, 1994). 
complementary, set of theoretical perspectives, so that some kind of coherence in the curriculum as a whole can be achieved. This is important from both a curricular and pedagogical point of view because it will also aid students in navigating a potentially bewildering range of disparate theoretical histories and agenda.

Secondly, musicology has a potentially important role to play in both expanding the field of popular music studies, in terms of enlarging the historical purview of the field and, at the same time, helping to integrate it within the study of music history as it is currently practiced and taught in the academy. Far too often, courses in popular music have been added to the music curriculum in a haphazard fashion and, in some instances, as a simple expedient-as a way of demonstrating to university administrations that music departments can be "relevant," and as a way of attracting large numbers of students from outside the discipline. In most cases, such courses have been taught by parttime faculty, or by full-time faculty with only a peripheral interest in the area, and exist outside the music curriculum proper (i.e., they are generally not among the courses required of students majoring in music). More importantly, such courses are often limited to histories of rock or post-World War II popular music, thus effectively isolating them from the mainstream of music history, both temporally and stylistically, as it is presently taught in most university music programs. The vast majority of university courses in popular music, whether they are taught within or outside of music departments, have tended to focus on histories of rock, with only passing reference to older forms of pop, such as Tin Pan Alley, or other traditions, such as jazz and blues. However, the growth of the field of popular music studies may require that a deeper level of historical awareness be developed - an awareness of not only early twentiethcentury popular music, but also that of the nineteenth century, where the roots of a commercial music culture, based in sheet music and live performance, in parlour songs and piano etudes, minstrelsy, music halls, café concerts, cabarets, and other forms, can be found. In many ways, this type of awareness can be achieved in courses in media, popular culture and/or cultural studies-a literature devoted to these nineteenth-century forms already exists-provided that individuals teaching in these fields take a more historical approach in developing courses in popular music. Musicologists could play a special role in this regard, however, by integrating the study of these more popular forms with that of the traditional repertoire, thus breaking with the idealized vision of art music that has characterized most music history of the past and, in the process, exposing music students to the full gamut of musical life and culturea culture that was at least as complex, contingent and riddled with contradictions in the nineteenth century (and earlier) as it is today.

To do so, however, may well mean that something else will be lost, that the inclusion of these new topics of study will inevitably displace some cherished element - a Schubert quartet, a song cycle by Schumann - of the conventional curriculum. But while difficult choices will undoubtedly have to be made, other benefits will also accrue. Not least among them will be a better integrated sense of "history" among our students: that is, a history that is not simply a linear, 
insulated, highly selective and one-dimensional sequence of musical styles and personages, but one that is more diverse and rich in its own own right and, at the same time, deeply resonant with contemporary life and experience.

If a model exists for how a transformation of this type can occur within musicology, it can perhaps be found in the not-so-distant field of ethnomusicology. Certainly, significant divisions-ideological as well as methodological-have long separated conventional musicology from ethnomusicology. But during the past decade, ethnomusicology has evolved into a vibrant discipline capable of encompassing the study of traditional musics of the world and those associated with contemporary forms of popular culture. Not surprisingly, many of the ethnomusicological accounts of popular music have maintained a clear sense of cultural and historical specificity. ${ }^{13}$

But even more important for my argument is the manner in which some of this work can also help us to rethink the nature of music and cultural history. In Veit Erlmann's recently published study of music in South Africa, ${ }^{14}$ for example, we are challenged not to think of the creative (and mutually exploitive) relationship between Paul Simon and Ladysmith Black Mambazo during the 1980s as simply a manifestation of some vague, new globalized culture, but rather as the outcome of a long history of such exchanges extending back into the late nineteenth century. Erlmann explores the ways in which the rise of modernity involved not only the reconstruction of Western identity around imaginary notions of "Africa" and various "others" but, equally, the construction of an African identity around notions of "the West." His account of this simultaneous, mutual imagining and its various manifestations in music should cause us to reconsider many of the other cherished dualities that underlie much conventional musical thought-such as the supposed opposition between tradition and modernity, Western and non-Western music, high and low culture, authenticity, and commercialism, among others-in order that we recognize what is in fact the inescapable interdependence of these concepts, and the ways in which this can be made evident through the careful examination of the musical practices and cultural contexts with which they are associated.

But the contribution of the music academy to the development of a broad, multi-disciplinary curriculum in popular music studies should not be limited to simply the realization of a more open and diverse form of music history; if that were the case, then one might assume that we are perhaps already half way towards such a goal. The efforts of musicologists, however, must also be matched by those engaged in other areas, such as music theory and analysis, performance, and composition as well. In theory and analysis, some work has

13 Among some of the best and most well-known studies are those published in the University of Chicago Press ethnomusicology series: including Christopher Waterman, Juju: A Social History and Ethnography of an African Popular Music (Chicago: University of Chicago Press, 1990); Peter Manuel, Cassette Culture: Popular Music and Technology in North India (Chicago: University of Chicago Press, 1993); and Jocelyne Guilbault, Zouk: World Music in the West Indies (Chicago: University of Chicago Press, 1993).

14 Veit Erlmann, Music, Modernity, and the Global Imagination: South Africa and the West (Oxford: Oxford University Press, 1999). 
already been done, ${ }^{15}$ but, again, a more interdisciplinary approach and a set of analytic tools appropriate to popular music forms are still very much needed. For example, analyses of rock music such as those conducted by John Covach and others ${ }^{16}$ seldom stray far from conventional concerns and methodologies of traditional music theory; in this sense, they may have the advantage of being easily assimilable within traditional courses in musical analysis but do not, to my mind, illuminate the music in significant ways; neither do they challenge basic assumptions about the nature of the musical "work" and its mode of analysis. The work of David Brackett, ${ }^{17}$ on the other hand, is more interdisciplinary in character, concerned with the analysis of musical texts as objects deeply embedded within specific historical contexts and musical/stylistic value systems. His analyses are sensitive to subtle variations in the performance of pitch, rhythm, and sound that work within, yet go well beyond, the boundaries of conventional theory and analysis and, in many ways, may serve as a more appropriate and meaningful model for the analysis of popular music in the future.

What is most important in the work of Brackett, however, is not only that it demonstrates an ability to combine socio-cultural and musical/analytic modes of interpretation, but that it also exhibits a theoretical and methodological flexibility that acknowledges the importance of adapting interpretive strategies to the demands of different musical texts and styles. These qualities make his work both intelligible and illuminating to a wide range of audiences-a characteristic that has been sorely lacking in much musical analysis of the past, whether it be based on conventional methods of notation and analysis or on more obscure scientistic and mathematical models. Indeed, one of the challenges to contemporary theory and analysis will be whether it can break with the historical trajectory that has characterized much of its development in the twentieth century, and adapt itself to a similar level of flexibility addressing, in the process, a different kind of music and a different, less specialized, audience.

In some ways, one of the most profound (and perhaps most difficult) contributions that the traditional music academy (and, to a lesser extent, the professional colleges) could make to the development of a curriculum in popular music studies is to offer a context in which popular music can be experienced as a form of "practice," not simply as an "object" to be studied. I speak here not in terms of the more general sense of "cultural practices,"encompassing a wide range of specific individual and institutional practices that are central to the production and consumption of popular music as they

15 In many ways, the early theoretical work of John Shepherd and Richard Middleton constitute a significant contribution to the foundations of a new kind of theorizing about popular music. As well known as the work of these scholars is in popular music circles, however, they appear to have had less of an impact in the arena of traditional music theory and analysis. As the development of a proper set of analytic tools comes to be felt within more traditional areas of the music academy, perhaps this work will receive its due.

16 John Covach and Graeme M. Boone, eds., Understanding Rock: Essays in Musical Analysis (New York: Oxford University Press, 1997).

17 Brackett, Interpreting Popular Music. 
are currently understood within much of the present literature on popular culture - but rather of that more conventional and limited understanding of the term within music and technical schools: as a set of primarily compositional and performance-oriented activities that constitute music-making in the first instance. I hasten to add, at the outset, that I do not entirely agree with this latter definition of the term, especially in its implied conflation of a specific set of acquired "skills" with musicality (or technical understanding) per se, and in its more or less explicit institutional and pedagogical aim of producing a class of "professionals" as practitioners. This is precisely where the difficulty lies.

Students of popular music could gain immense insight into the processes of musical production and distribution through greater exposure to the fundamentals of music performance (i.e., to the fundamentals of pitch, rhythm, vocal and instrumental performance, though not necessarily via the medium of notation), to the various aesthetic and technical practices associated with electrical amplification, sound recording and digital technologies (not to mention analogue technologies such as turntables), and to the decision-making processes that take place on a day-to-day basis in the record industry, in the press, in night clubs and concert booking agencies, and in the radio, television, and telecommunications industries. ${ }^{18}$ Exposure of this kind, in some but not all these areas, can and does take place in departments of communications or media studies and, to a lesser extent, in programs devoted to cultural studies; however, it is in departments and faculties of music, and in technical or polytechnic colleges, that the majority of the instructional infrastructure for such programs of study currently exists and where it is, for the most part, devoted to overly specialized, professional training of one type or another. My point here should not be taken as a polemic against the training of professional musicians, recording engineers, or music managers, as such, but as a concern with the ways in which particular definitions of professionalism can effectively exclude individuals engaged in creating certain styles of popular music, and with how a singleminded focus on professional training can work against the more general pedagogical aims of a broad education in popular music studies.

One of the immediate, structural problems with the conventional orientation to professional training, both within the music academy and in the polytechnic schools, is the manner in which it leads to high levels of specialization that may not be entirely relevant to popular music. For example, the distinction between performance and composition-a distinction that is reinforced through separate departmental structures in most of the larger faculties of music-is not as clearly defined in many popular styles of music making as it is in the classical music tradition. A more integrated approach to the teaching of music theory, composition, and performance may be required. Similarly, while there

18 In my own experience of teaching popular music, it is not unusual to find a certain number of students enrolled in such courses who are already members of bands, actively engaged as DJs, or working in campus radio stations, and the like. Creating opportunities for them to further their knowledge and skills in these areas as well as for those who are not already engaged in such activities should be among the goals of any program in popular music although, in any given institution, the means of pursuing these goals may not be equal in all areas. 
is certainly a need for specialized and highly trained engineers in the areas of live sound reinforcement, sound recording, and mixing within the industry (a market to which the polytechnic schools and university programs, such as McGill University's "tonmeister" program, have almost exclusively dedicated themselves), it is also clear that the composition and performance of popular music are completely integrated with sound technologies at the most fundamental levels, and that a general understanding of audio technology and technical practices should be considered as important components in the development of any and all forms of popular musicianship. And while many university music programs have begun offering introductory courses in music technology as a general requirement in undergraduate curricula, "technology" in these instances has too often been defined simply in terms of computers and software, rather than in terms of the wider range of technologies and technical practices that are characteristic of popular music. These are areas in which difficult battles over facilities, and fiscal and curricular priorities, will no doubt have to be fought: the balance between specialized facilities dedicated to professional training and lower level, general access facilities, needs to be addressed, as does the issue of the type and range of technologies that can be supported.

At an entirely different level, the introduction of popular music into traditional music departments and faculties raises important questions concerning the ways in which music performance is conceived and evaluated. Typically, the performance of classical music begins with a score-an historical document associated with certain conventions of execution and interpretation against which the specific technical and interpretive abilities of the student can be evaluated. Jazz has been more or less fully assimilated into many music departments in North America (even though its traditions are less dependent on the existence of detailed musical scores), in part, because its performance values are associated with a certain level of virtuosity, and its stylistic traditions are sufficiently well understood (through the analysis of the recorded repertoire) to support the evaluation of technique and improvisational ability in a manner that is consistent with (albeit different from) the norms of classical music. The conventions of popular music performance are considerably more variable, however: in some genres, such as the various styles associated with heavy metal and hard rock, technical virtuosity, and improvisational invention are central values that can be relatively easily assimilated to conventional methods of performance evaluation; ${ }^{19}$ even the turntable techniques associated with DJs in hip-hop and dance culture lend themselves to such a treatment. In other genres, however, such as those associated with the pop singer/songwriter tradition, instrumental performance may be more intimately tied and/or subordinated to lyrics, song structures, visual gestures, and the like, thus making evaluation a more complex problem. In various genres descendant from the

\footnotetext{
19 Of general relevance to this discussion is a provocative article on the relationship between metal virtuosity and classical music by Robert Walser, "Highbrow, Lowbrow, Voodoo Aesthetics," in Microphone Fiends: Youth Music \& Youth Culture, ed. Andrew Ross and Tricia Rose (New York: Routledge, 1994), 235-49.
} 
punk movement, the projection of a distinct lack of technique may be the object of performance; and finally, in the myriad genres and sub-genres associated with contemporary dance music, the use of sampling and other techniques calls into question the definition and value of musical performance at a fundamental level..$^{20}$

If popular music is to be accepted within the curriculum of traditional music departments and faculties, some of these evaluative issues will have to be addressed. But doing so cannot take place in the absence of a thorough understanding of the contexts in which pop music is produced and consumed, for it is there that its meaning and significance is ultimately determined. And, in this sense, the pedagogical solution to the problem of evaluation (and other problems like it) may well lie, again, in developing a broad, interdisciplinary understanding of popular music and its relationship to music pedagogy as a whole.

The myriad difficulties that will inevitably be encountered in any attempt to integrate popular music within conventional music programs, and the even more complex practical problems associated with creating meaningful links with other disciplines of study, can only be hinted at here. But if popular music sudies is to have a future in the academy, then its current status as little more than a heterogeneous group of isolated, individual course offerings within specialized disciplinary contexts must come to an end, or rather, it must evolve into something more complex, more clearly articulated as an organized curriculum of study. As I have suggested throughout this essay, the courses that exist (and those that are yet to be created) need to be coordinated into a coherent multi- and interdisciplinary program that draws on the strengths of numerous, individual contributions, on the one hand, and also fosters the development of both common and complementary theoretical perspectives on popular music as a form of social, cultural, and musical practice, on the other. The precise configuration of programs and courses will most certainly vary, depending on local circumstances, and may include collaborations between a variety of departments and faculties as well as between universities and technical colleges. ${ }^{21}$

In the realization of such a project, faculties and departments of music may have a special role to play. Indeed, although their participation comes rather late and may require, as suggested above, a considerable rethinking of the structures and pedagogical practices associated with present-day higher edu-

20For a more thorough examination of these and a number of other evaluative problems associated with pop performance (as well as suggestions for their resolution), see Timothy Warner, "'I'll give it five': The Assessment of Popular Music Performance," Journal of Popular Music Studies 9-10 (1997-1998): 37-42.

21 Because of their primarily professional orientation, many technical schools do not, at the present time, support courses in popular music as a cultural phenomenon and, among those that do, students tend to find the material covered to be at best peripheral to their interests. However, this should not prevent technical schools and universities from collaborating where opportunities exist for their mutual benefit: for example, the newly launched joint graduate program in Communication and Culture offered by Ryerson Polytechnic and York University holds great promise for scholarship in a number of areas of media and culture, not least among them popular music studies. For an interesting discussion of the place of popular music theory in a primarily undergraduate technical school environment, see Paul D. Fischer, "'Do we really have to think about this stuff?': Music Industry Majors and Popular Music Study," Journal of Popular Music Studies 9-10 (1997-1998): 71-77. 
cation in music, it may still be a welcome one when we consider the potential benefits to both popular music studies, specifically, and to music education as a whole. For our understanding of music, in all its diversity, can only be enhanced by a more broadly based, multi- and interdisciplinary approach to music scholarship. The recent appearance of works such as Georgina Born and David Hesmondhalgh's Western Music and Its Others ${ }^{22}$ bears testimony to the richness and depth of insight that can be gained through such an approach. While certainly not the first study of its kind to investigate the orientalist and exoticist impulses in the history of Western music, it is certainly among the more far-ranging in terms of the sheer number of disciplinary perspectives that it brings to bear on its subject-including contributions from anthropology, ethnomusicology, film and media studies, historical musicology, sociology, and popular music studies-and in terms of the range of musical styles addressed-including music in the classical tradition, jazz and avant-garde composition, film music, a variety of pop and rock styles, and World Music. To my mind, the existence of a literature of this kind may well signal the beginnings of a more profound interdisciplinary project—a project towards which much conceptual and practical work must now be addressed.

\begin{abstract}
Arguing that past attempts at introducing popular music into the curriculum have taken place primarily at the level of the individual course, the author argues that a more extensive and integrated approach to developing academic programs in popular music is now needed. The model for such a program must be both multidisciplinary and interdisciplinary in character and must include the full participation of departments and faculties of music. Consideration is given to the special demands placed on music programs in terms of the need to rethink the structures and pedagogical practices associated with present-day higher education in music.
\end{abstract}

22Georgina Born and David Hesmondhalgh, eds., Western Music and Its Others: Difference, Representation, and Appropriation in Music (Berkeley: University of California Press, 2000). 